\title{
O PLURALISMO CULTURAL DOS IMAGINÁRIOS SOCIAIS MODERNOS SEGUNDO CHARLES TAYLOR
}

\author{
Joel Francisco Decothé Junior ${ }^{1}$ \\ Universidade do Rio dos Sinos (UNISINOS) \\ (iD) http://orcid.org/0000-0002-9499-1233 \\ E-mail: joeldecothe@yahoo.com.br \\ Kelvin Felipe Weschenfelder ${ }^{2}$ \\ Universidade do Rio dos Sinos (UNISINOS) \\ https://orcid.org/0000-0002-4140-0575 \\ E-mail:klvkfw@hotmail.com
}

\section{RESUMO:}

Charles Taylor, ao refletir sobre o pano de fundo histórico-cultural da modernidade ocidental, estabelece a tarefa hermenêutica de fazer uma releitura das múltiplas facetas dos imaginários sociais modernos. Esses imaginários acabam sendo diversificados em uma pluralidade triádica e constitutiva de múltiplas formas culturais. Assim, conforme assevera o filósofo canadense, temos a esfera da moderna faceta social que está sob a égide da economia. De modo que essa é entrelaçada com a face estrutural da modernidade como esfera pública. Por fim, e, sem menos importância, encontramos o autogoverno do povo em seu aspecto nuclear de soberania democrática. Então, neste texto, nutrimos a intencionalidade de acompanharmos o pensamento de Taylor, em sua reconstrução delineadora deste tipo de pluralismo, que examina sobre as fontes, ideias e práticas democráticas articuladas a partir destas facetas constitutivas e articuladoras dos imaginários sociais modernos.

PALAVRAS-CHAVE: Pluralismo; Cultura. Imaginários; Modernidade; Democracia.

\section{THE CULTURAL PLURALISM OF MODERN SOCIAL IMAGINARIES ACCORDING TO CHARLES TAYLOR}

\begin{abstract}
:
When Charles Taylor reflected about the background history-cultural of occidental modernity, he sets the hermeneutic task to do a rereading on the multiple facets of social modernity imaginaries. These imaginaries ended up being diversified in a plurality triadic and constitutive of multiple culture forms. In this way, how asserts the Canadian philosopher, there is a sphere of the modern social facet that is under the aegis of economy. Which is interlaced with the structural face of modernity as a public sphere. Finally, we have the Self-Government of the people in your nuclear aspect of democratic sovereignty. In this paper, we have the intention to follow the thought of Taylor, in your reconstruction of this pluralism type, that examines about sources, ideas and practices democratic articulated from these constitutive facets and articulator of modern social imaginaries.
\end{abstract}

KEYWORDS: Pluralism; Culture. Imaginaries; Modernity; Democracy.

${ }^{1}$ Doutorando na Universidade do Vale do Rio dos Sinos (UNISINOS), São Leopoldo - RS, Brasil.. Bolsista CAPES-PROSUC. .

${ }^{2}$ Grupo de pesquisa Filosofia Política, Normatividade e Dialética - Universidade do Vale do Rio dos Sinos (UNISINOS), São Leopoldo- RS, Brasil. Bolsista PROBIC/FAPERGS.

JUNIOR, Joel Francisco Decothé; WESCHENFELDER, Kelvin Felipe. O pluralismo cultural dos imaginários sociais modernos segundo Charles Taylor. Griot : Revista de Filosofia, Amargosa - BA, v.19, n.2, p.250-264, junho, 2019. 


\section{Introdução}

O filósofo canadense Charles Taylor ao analisar os desdobramentos da modernidade pós-industrial e pós-guerras, busca compreender as instâncias dos imaginários sociais modernos, esses que nos dias de hoje desenvolvem um papel fundamental para com o rumo de nossas sociedades. Para que sua tarefa seja mais precisa, procura na história o início e os principais pontos no desenvolvimento desses imaginários.

Esses imaginários se comportam de uma forma triádica, cada um com seus fundamentos, história e foco. Podemos separá-los em: (I) a faceta da economia; (II) a faceta da esfera pública; e (III) a faceta do autogoverno. Dentre essas, o destaque fica para a economia que ocupa o cargo, ainda nos dias de hoje, de desígnio da vida social entre os seres humanos. Essa meta, que nem sempre foi o foco das civilizações, fortaleceu os vínculos de diferentes culturas em busca de condições mútuas de qualidade de vida.

Ainda que a economia exerça um papel fundamental sobre os indivíduos modernos, sua extensão não é total. A esfera pública realiza o objetivo de desenvolver um campo de debate que em suma, alicerçado na razão, busca o interesse do povo pré-políticamente, uma vez que define as bases para que um governo possa exercer o seu desígnio. Por fim, após as bases da necessidade política, temos o autogoverno que é baseado na razão necessária da soberania democrática de um povo. Desse modo, temos um modelo triádico que desenvolve seu papel fundamental da manutenção das sociedades modernas, nas quais Taylor busca compreender a partir de uma extensa analise sobre seus limites e anseios.

\section{A economia como normatividade imagética comum}

A vida cultural da modernidade tem os seus avanços e desdobramentos centrados em um eixo tripartite segundo a reflexão de Charles Taylor. Estes espaços são estabelecidos de uma forma metatópica, extrapolítica e secularmente de uma forma entrecruzada. Contudo, a primeira faceta a ser concebida como fato na modernidade, segundo o filósofo canadense, e que é colocada em voga é a da economia. A estrutura social moderna teve como um de seus vetores a economia. Logo, se o pensamento político da época propagou o telos da sociedade como agir de benefício mútuo, pois assim seria garantida a seguridade e a prosperidade econômica. Esta disposição moral entende a sociedade como uma arena de câmbios que podem potencializar faceta social desta como economia. Porém, mesmo que a economia tenha desempenhado um papel importante, a sociedade moderna não se estende para outros aspectos políticos que alcançam até os dias atuais com a sua devida força ordenadora.

Entretanto, a força da economia se impôs de tal forma que tudo indica que ela vem sendo encarada como a meta principal da vida social até os dias de hoje. Aqui temos uma mudança significativa, pois se na era antiga e medieval a plenitude de vida era alcançar as práticas virtuosas em sua totalidade e, com o advento da ordem moral econômica moderna, o objetivo passa a ser o de benefício mútuo por meio das relações econômicas dadas na vida cotidiana. Assim, "os seres humanos

JUNIOR, Joel Francisco Decothé; WESCHENFELDER, Kelvin Felipe. O pluralismo cultural dos imaginários sociais modernos segundo Charles Taylor. Griot : Revista de Filosofia, Amargosa - BA, v.19, n.2, p.250-264, junho, 2019. 
estão inseridos num intercâmbio de serviços. $O$ modelo fundamental parece ser o que apelidámos de economia" (TAYLOR, 2010a, p. 74). A escalada de compreensão da sociedade como eminentemente econômica está atrelada a diversas razões.

As razões materialistas se unem as operações comerciais dando extremo poder aos novos empreendedores. Ademais Taylor busca outras razões para esquadrinhar esta época, pois tanto os elementos políticos como espirituais configuraram tal época. O filósofo canadense não encerra as explicações para as mutações ocorridas no fator econômico, mas este dado econômico se junge com o entendimento de que a sociedade em sua deve ser cada vez mais educada e civilizada, sendo esta via a mais adequada para a viabilização de uma sociedade propicia ao comércio. Esta visão partia das camadas poderosas que tinha o poder de governar nas mãos. Os nascentes governos estatais na modernidade vinham tomando ciência "de que a produção aumentada e o intercâmbio favorável eram uma condição-chave de poder político e militar" (TAYLOR, 2010b, p. 219). Logo, para que estas circunstâncias se tornassem algo factual, tais ações governamentais eram direcionadas a vida ordenada e disciplinada tendo em vista as ocupações econômicas que todos os indivíduos deveriam exercer disciplinadamente. Estas ações econômicas acabaram erradicando a desordem social de outrora causadas pelas constantes guerras, instalando assim os predicados civilizatórios da paz imanente as sociedades nascentes. Para além desta concepção econômica de sociedade, Taylor assevera que aconteceu uma mutação nas condições de crença espirituais, ou seja, o que se deu foi a firmação da vida cotidiana.

Esta situação exigia que a vida fosse cada vez mais sendo ordenada e disciplinada, pois assim o poder estatal ia operando na esfera social. Esta forma de ordenamento da vida também era uma exigência religiosa protestante e, em certa medida, vinha sendo assumida pelas fileiras católicas. Desta forma, a afirmação da vida cotidiana, faz uma oposição à noção de vida boa que estabelecia esta como um exercício da certas atividades que eram consideradas como superiores. A partir desta concepção a vida deveria ser dedicada ao trabalho, a produção e a família, instaurando assim a desconstrução das hierarquias vocacionais e profissionais.

Observe-se que a afirmação da vida cotidiana constitui no pensamento de Taylor o pano de fundo que fixou uma série de fraturas centrais para dentro da sociedade contemporânea no Ocidente. Isto fica mais evidenciada se nos pomos a pensar sobre a relevância da própria economia e o axioma da igualdade liberal nas composições sociais de hoje. Cabe frisar que a economia ostente uma estrutura rígida que é regida pelas suas próprias leis. A economia ocupa um espaço metatópico, conforme esta vai estabelecendo concatenações a partir de múltiplos atos egoístas que são levados a finalidade de beneficiar-se pessoalmente. Assim, a economia constitui uma esfera abertas a ações simultâneas que geram influências de natureza reciproca que são orientadas pelas próprias leis econômicas, mesmo que se tenha uma ligação na correlação de forças pessoais.

O que se faz possível é o ato de previsibilidade dos resultados, em razão de suas leis rígidas, que são direcionadas as junções das ações individuais. Segundo as reflexões de Gasda, nas sociedades hierarquizadas, a justiça distributiva será o vetor organizador da vida societal. Porém, nas sociedades democráticas, onde todas as pessoas possuem igual importância, "substituiu-se a noção de honra pela noção de dignidade inerente aos seres humanos. A premissa é que todos partilham desta

JUNIOR, Joel Francisco Decothé; WESCHENFELDER, Kelvin Felipe. O pluralismo cultural dos imaginários sociais modernos segundo Charles Taylor. Griot : Revista de Filosofia, Amargosa - BA, v.19, n.2, p.250-264, junho, 2019. 
dignidade" (GASDA, 2016, p. 2016). Sendo assim, mesmo com a introdução da noção de dignidade, o que também vemos é o surgimento na modernidade de uma ciência que tem a pretensão de objetificar a sociedade e os seus fenômenos com as suas próprias leis, nos mesmos moldes dos fenômenos naturais.

No entanto, conforme vai se assumindo que a sociedade moderna seja configurada por uma concepção de real que é guiada pelas leis rígidas da economia, aí temos a possibilidade de entendermos que a espécie humana passa a ser interpretada como uma gama de grupos que tem a tarefa de construir e a manipular a vida real. Isto se dá da mesma forma com a natureza em sua volta, pois nesta casa Taylor irá explanar algo sobre as demais formas de articulação dos imaginários sociais modernos que constam nas facetas da esfera pública e do autogoverno soberano do povo. Ademais, temos uma via de mãos dupla onde que configuram este novo modelo social, pois hora temos categorias passivas e, outras vezes, temos aspectos ativos para a própria construção de identidades populacionais que são fragilmente enquadradas nas condições de receberem modelações econômicas.

Contudo, além desta possível passividade, podemos notar que estas mesmas populações podem se tornar ativas na construção de suas histórias. De modo que estas políticas impostas pelas instituições podem ser alvos passivos de mudanças ativas operadas pelas populações. A questão que fica em evidência como fato de transição, se encontra na compreensão da sociedade como um fator exteriorizado ao campo político. Se tomarmos como lente de entendimento do fenômeno social a categoria da economia, temos que pressupor que a sociedade em termos de associações que agrupam pessoas que não se identificam em termos de unidade identitária por razões políticas, mas pela racionalidade e interesses econômicos. Isto ocorre como um processo que tem como pano de fundo um veloz crescimento das necessidades de consumo, que sinalizou um dos pontos de construção do imaginário social moderno. Assim, podemos notar que tal assertiva não depende de qualquer espécie de explicação etiológica que nos remeta a causas originárias de natureza religiosa ou até mesmo sendo "explicado apenas pela remissão ao desejo crescente de autenticidade pessoal" (HONNETH, 2015, p. 371).

O resultado deste deslocamento da mentalidade que privilegiava a sua unidade em torno de fatores políticos, se trasladou para elementos de interesse econômico. Isso resultou no erguimento da concepção de sociedade civil. Logo, a economia se impõe como a prática que nos ajudará a entendermos as ações sociais fora deste eixo de unidade política, algo que com o desenvolvimento deste tipo de modelo social irá de espraiar para outras formas que poderão ser analisadas em termos demográficos, culturais e morais. Assim, a sociedade passou a ser vista como desvinculada ao corpo político, pois as suas ações se difundem para mais variadas e livres operações, sobretudo, as econômicas. Em outras palavras, "a sociedade foi desligada do "regime político" e flutua agora, livre, no meio de várias aplicações diferentes" (TAYLOR, 2010a, p. 83). Vê-se, então, que o prima de compreensão sore a sociedade que gera as condições necessárias de examiná-la desde os mais diversos ângulos possíveis, torna-se uma realidade. Aqui temos um afastamento significativo do horizonte teológico como fundamento da era medieval religiosa com a sua teleologia divina. O problema é que conforme a sociedade está sendo concebida como a materialização de uma série de ideias e formas preconcebidas desde a eternidade,

JUNIOR, Joel Francisco Decothé; WESCHENFELDER, Kelvin Felipe. O pluralismo cultural dos imaginários sociais modernos segundo Charles Taylor. Griot : Revista de Filosofia, Amargosa - BA, v.19, n.2, p.250-264, junho, 2019. 
que teriam o poder de normatizar rigidamente a ordem moral da sociedade, não existira a possibilidade de se construir uma nova realidade onde se possa agir. Isto porque a realidade social estaria estigmatizada por uma forma de normalização onde a ação livre é freada pelo determinismo ontoteológico.

Taylor segue ponderando que a crise da fé em Deus foi produzida numa espécie de junção com a crença numa ordem moral de indivíduos com direitos que tinham de ser operados em seu próprio favor. Esta situação nega a máxima precedente que versava em torno de uma posição ética que estimava a questão moral da honra. Esta ética pautada na honra exaltava a imagem do guerreiro, sendo o resultado disto o eclipse do horizonte de transcendência como dispositivo de ação do agente humano. Esta perspectiva influenciou centralmente, "as formas do imaginário social predominante no mundo ocidental, a saber, a economia, a esfera pública e o poder soberano do povo" (TAYLOR, 2015, p. 95). Desta forma temos uma negação da compreensão finalística da sociedade baseada em um tempo superior, onde se calcavam as visões escatológicas do fim da história. Com esta fratura da visão absoluta do tempo radicada em termos transcendentes, a sociedade moderna, não adota mais soberanamente o tempo em categorias teológicas.

Para Taylor, pondera que a sociedade vai tomando consciência de que as esferas do sagrado e do profano fazem parte da imanente esfera pública política. Mesmo assim a esfera que está além da política pública, ou seja, a da vida privada comporta também a vida econômica das pessoas em seus espaços da ação privada. Logo, o indivíduo que passa a dedicar a sua vida a produção, a atividade econômica, passa a ser encarado como um sujeito que tem a sua vida privada marcada pelas operações ligadas a economia. Tal fim tem como meta o ato de produzir em benefício próprio ao fazer transações particulares de bens e riquezas. Esta interferência privada na produção econômica viabiliza a construção de espaços metatópicos, descolados da política e secularizados onde se constitui uma práxis legitimamente econômica. Sendo assim, a economia pode ser encarada como a primeira esfera que constitui esta nova faceta da história que é a modernidade. A faceta econômica da modernidade ofereceu os elementos necessários para que a esfera pública viesse a fazer parte da estrutura cultural desta era.

A sociedade vista com um olhar estritamente econômico, acaba demonstrando que as grandes mudanças que foram operadas na modernidade se deram com a força deste vetor. Este impulso agiu como um conjunto interconectado de ações, que fomentaram a produtividade de bens e a sua comercialização. Tudo isto se deu por meio de intercâmbios internacionais e da expansão do mercado de consumo, que se constituiu como um sistema que detém as suas próprias leis e dinâmicas de articulação organizativa. Taylor argumenta que a concepção de economia confere a sociedade uma espécie de identidade extrapolítica em que, "a economia define agora uma dimensão da vida social em que funcionamos como uma sociedade potencialmente fora do âmbito da política" (TAYLOR, 2014, p. 232). Ao encarar a malha social como que atravessada pela economia, onde se forjam um conjunto de relações que operam com uma lógica própria com respaldo dos agentes humanos. A economia compõe parte importante dos novos imaginários sociais modernos, pois além do avanço da racionalidade instrumental do mundo vivido, porém temos ainda "a invasão crescente da economia e da administração no mundo

JUNIOR, Joel Francisco Decothé; WESCHENFELDER, Kelvin Felipe. O pluralismo cultural dos imaginários sociais modernos segundo Charles Taylor. Griot : Revista de Filosofia, Amargosa - BA, v.19, n.2, p.250-264, junho, 2019. 
vivido, o que Habermas chama de colonização do mundo vivido" (OLIVEIRA, 1993, p. 17). Esta perspectiva teve sua gênese no século XVIII e se estende até os dias atuais com o neoliberalismo, sendo estas noções fomentadas pelas esferas intelectuais, chegando ao ponto de se tronar um pensamento bastante popular.

Os sujeitos modernos começam a idealizar os imaginários sociais perpassados por relações econômicas onde se busca certa prosperidade e segurança, se dando por meio de intercâmbios de bens para que aconteça o mútuo benefício. Percebemos que Taylor ao pontuar a valorização e afirmação da vida cotidiana entende que esta categoria se tornou um dos objetivos centrais da cultural moderna. Isto porque a afirmação da vida cotidiana tem sua correlação com uma espécie de relação econômica da casa em que se "pretende em linhas gerais, designar a vida da produção e da família" (TAYLOR, 2013, p. 28). O que sucede é o abandono da providência divina e tomada de posição onde o agente humano passa a ser modelada e controlada por si mesmo. Como implicação da manipulação da natureza objetivamente, passasse a desenvolver a expansiva sofisticação da ciência, da tecnologia e de uma série de fatos e estatísticas que abarcam um conglomerado variado de situações tais como a saúde, a educação e a vida em geral da população (GIROLA, 2007, p. 53). Podemos frisar que a confiança nesta nova forma de conhecimento, que é a economia, conta com a apologia das possibilidades trazidas pela mesma em termos de futuro da humanidade, sendo algo que marca centralmente esta faceta social da modernidade.

\section{A estrutura da esfera pública como espaço democrático alternativo}

O desenvolvimento de nossa análise que leva em consideração o prisma das três facetas da modernidade, refletidas por Taylor, desemboca agora na questão da esfera pública que ostenta basicamente dois sentidos. Num primeiro momento, temos o sentido manifesto que é remetido às circunstâncias que implicam os interesses gerais do povo. No caso do momento seguinte, a alusão se dá naquilo que é de conhecimento de todo o povo e que confere a todos as condições de igualdade necessária de acessibilidade pública. Nesta perspectiva, a esfera pública toma como base fundacional, à noção de interesse e acesso universal as questões públicas. Taylor assevera que o surgimento da esfera pública tem determinada conexão com os desdobramentos da noção de ordem moral moderna. Esta situação tem sustentação em dois aspectos importantes, a saber, no seu reflexo extrapolítico e na força popular legitimadora da moderna noção de ordem moral dentro do campo do imaginário social vigente.

A esfera pública acaba sendo caracterizada pela independência forte do que venha a ser o político, pois assim, consequentemente, o que se vê é o critério de sua legitimidade cultural que se arvora como uma renovada ação de sustentação das bases da própria ordenação moral. A fundamentação ético-política que advém desta estrutura denota agora a ação de luta por direitos de igualdade entre seus membros, ou seja, o elemento pré-político e a postura de associação livre e voluntária do povo se dá por meio da noção de consentimento popular ao poder governamental. Logo, nesta ordem moral moderna é o conglomerado de indivíduos que consente em ser governado, e isto, para que tal governo seja exercido sobre suas vidas, no intuito de

JUNIOR, Joel Francisco Decothé; WESCHENFELDER, Kelvin Felipe. O pluralismo cultural dos imaginários sociais modernos segundo Charles Taylor. Griot : Revista de Filosofia, Amargosa - BA, v.19, n.2, p.250-264, junho, 2019. 
lhes garantir as condições necessárias para que a operação da dinâmica que a própria sociedade política organizada impõe a ser alcançada como aquele diapasão de suas metas.

A estrutura social moderna é regida pela noção de contrato onde a força social se manifesta como agência coletiva de seus membros em termos de eficácia, pois desta forma e por este meio, os agentes humanos em junção coletiva, podem reivindicar as determinadas exigências acordadas normativamente. Assim, o elemento do consentimento popular vai se constituindo como fundamento de toda a legitimidade política, desta feita, faz-se viável a mutação e acabamento de tal noção como o critério permanente que confere legitimidade ao poder político institucional. Isso porque este se erige como premissa central para a regulação legitima desta ordem moral moderna. Esta seria a base dual que articula a esfera pública política em sua fase genética, isto é, o poder delegado pelo povo por via do consentimento e legitimidade de governança dos gestores incumbidos de fazer a gerência da dinâmica social da ordem moral da esfera pública secular. Taylor encara tal situação de emancipação política como um movimento benéfico de autorrealização dos indivíduos em meio à coletividade, desta forma o entendimento é o de que os modelos de "autorrealização dos indivíduos, que por muitas vezes tendem a gerar tipos de subjetivismo, são compreendidas por Taylor como modos de ser da própria modernidade" (ARAUJO, 2004, p. 167). Podemos ventilar a noção de que a esfera pública se configura num espaço de debates externos ao próprio poder político. Então, o seu traço marcante se mostra no fator extrapolítico, que ademais o poder político estatal começa a ter que dar inevitável atenção.

Nesta perspectiva a esfera pública começa ser o âmbito de maior interesse da própria ação política. A esfera pública materializa um espaço de debates que não se restringe ao do poder político. Contudo, estes debates não estão alheios à força do poder político, porém não represente substancialmente a articulação do uso deste poder para legitimar tal discussão. Sendo assim, a condição metapolítica que estas ações comunicativas exercem na esfera pública acaba sendo algo central em sua constituição. Ademais, a inovação que a esfera pública acaba por trazer não se fixa na questão do critério de demarcação do espaço metapolítico, isso num sentido de ser uma esfera que tem a pretensão de controlar toda e qualquer ação política, mas o que emerge é a realidade de que o ponto de controle que exerce sua força é o da racionalidade humanista. Deste modo a constituição da esfera pública moderna instaura a noção de que o poder político precisa ser fiscalizado e regulado por alguma espécie de poder externo a este. A partir disso, Taylor conceitua que "o imaginário social, pode ser denominado de uma instância essencial na formação dos sujeitos, tal qual um etos fundamental na constituição das subjetividades" (OLIVEIRA, 2018, p. 199). Deste modo, a esfera pública não se define como a vontade divina ou a esfera de aplicação da lei natural. Mas, a definição é a de que esta se articula como um discurso que provem da razão e não do campo de poder e hierarquia vertical da tradição.

Podemos indicar que para Taylor o predicado metapolítico inovador que é trazido com o fortalecimento da esfera pública, se localiza naquele aspecto "constitutivo do discurso da racionalidade moderna sobre a para o exercício do poder, pois isso supera a noção de ser uma mera argumentação discursiva do e pelo

JUNIOR, Joel Francisco Decothé; WESCHENFELDER, Kelvin Felipe. O pluralismo cultural dos imaginários sociais modernos segundo Charles Taylor. Griot : Revista de Filosofia, Amargosa - BA, v.19, n.2, p.250-264, junho, 2019. 
poder" (TAYLOR, 2010a, p. 94). Conforme a opinião pública vai ganhando corpo, devido aos debates que são travados na esfera pública, a sua legitimidade vai sendo reconhecida. $O$ fator que estabelece este consenso é pautado pela reflexividade que este debate público oferece, e isto estava para além da mera opinião vulgar. As implicações normativas desta noção se revertem na importância que os governos têm de dar aos juízos emitidos a partir desta esfera. A legitimidade da opinião pública se estriba em dois aspectos importantes: (i) se ergue como o resultado de uma discussão pautada pela razão; (ii) representa a manifestação da opinião popular em sua condição de soberania. Taylor segue argumentando que a funcionalidade da esfera pública é a de estabelecer as condições necessárias para a formação da opinião consensual da malha social, sem estar necessariamente atrelada e mediada pela força da esfera política. $O$ debate se dava para além do poder político imperante, pois a esfera pública civil vai exercendo uma força normativa diante desta realidade do poder político governamental. O movimento será o de condução da esfera pública como um espaço metapolítico e secularizado. Então, a esfera pública é um ambiente em que se leva a termo uma meta em comum paralelamente a estatura do poder institucional.

$O$ aspecto que pode ser dado como evidente, se demonstra na presença da igreja como um espaço que sofreu em termos políticos em razão do processo intenso de secularização da esfera pública. Certo é que a esfera pública vai se constituindo como um ambiente aonde as associações vão sendo estabelecidas pelas interações coletivas expressas por meio de uma lente temporal secular, isto tendo em vista a finalidade de se erigir uma opinião pública comum. Esta perspectiva da opinião pública está em intensa relação com o agir político dos sujeitos e instituições. No espaço da esfera pública, estes agentes debatem os fins políticos que as suas deliberações irão tomar em termos de opinião comum, pois "o foco é o de observar os desvios de poder diante a própria realidade da opinião pública vigente" (FORERO REYES, 2010, p. 226). A estruturação destes arranjos públicos, que se dá por via das associações, tem a sua razão de ser por causa de suas ações coletivas que se dão estritamente dentre do fluxo da temporalidade secular. Assim, a secularização nesta linha de pensamento expressa à associação dos agentes humanos que interferem política e culturalmente na nascente esfera pública democrática. Este influxo dos agentes, estabelece uma agenda de ações coletivas que não mais se pautam pela noção de tempo superior, a saber, regido pelo senso do sagrado, que parta da dependência de uma fundamentação calcado no transcendente. Porém, passa a postar-se na base de uma concepção profana de tempo secularizado.

Vemos que neste processo, entre tantas questões a subjetividade moderna se seculariza, e entra num círculo de "ralações sociais mais herméticas do que numa relação dualística simples com uma pessoa soberana" (VATTIMO, 2018, p. 35). Assim nesta direção a esfera pública se constitui como um espeço comum onde entram em interconexão variadas opiniões referentes ao interesse popular, sendo este o seu primeiro dispositivo no que tange ao significado do que seja o público. Entretanto, a esfera pública também é o ângulo em que se relacionam questões que são da ordem da vida privada e nos remetem ao segundo significado do que venha ser o público, isto é, aquela da acessibilidade. Conforme, estamos argumentando a relevância do âmbito extrapolítico encontra-se na constituição dos novos espaços

JUNIOR, Joel Francisco Decothé; WESCHENFELDER, Kelvin Felipe. O pluralismo cultural dos imaginários sociais modernos segundo Charles Taylor. Griot : Revista de Filosofia, Amargosa - BA, v.19, n.2, p.250-264, junho, 2019. 
que foram sendo erigidos em termos de privacidade. Como sabemos, a economia foi o primeiro espaço privado, pois este espaço conforme a visão de Taylor tem sua fundamentação na noção de afirmação da vida cotidiana. Tal compreensão de vida boa tem a sua estatura epistêmica em dois vetores, a saber, a noção que se orienta na dedicação da vida a produção e a concepção de família. A vida em família acaba se constituindo como outro espaço de privacidade. Estes espaços privados da vida em família e a economia foram centrais para a configuração da própria esfera pública.

Estes espaços foram muito importantes para a configuração da vida moderna em sua particularidade. Mas, outros elementos que contribuíram para esta situação são tanto a força do extrapolítico e da secularização para que a esfera pública se formasse como realidade moderna. A Reforma Protestante está nas origens de articulação destes espaços privados, pois este movimento é o princípio espiritual ativo desta noção de afirmação da vida cotidiana. $O$ espeço privado da família requer outra espécie de privacidade, que se conforma num diapasão diferente do exigido pelo âmbito econômico. Esta forma de privacidade que se desenvolve no decurso do século dezoito e se concentra nas relações de intimidade. A convivência familiar estipula a necessidade da intimidade que influencia a escrita de boa parte da literatura deste século. Esta literatura se colocou a tarefa de demonstrar as relações íntimas como um espaço de adequado de louvor dos sentimentos nobres e refinados. De modo que tal literatura se forjou como uma via de divulgação desta recém construída noção de intimidade. Na filosofia de Taylor esta circunstância leva a compreensão de que "a vida pode ser descrita e administrada sem qualquer noção de transcendência. Ele chama isso de quadro imanente" (BERGER, 2017, p. 107). A vida privada nascente ajudou devera a que a esfera pública cada vez mais fosse ganhando força. Nesta esfera as opiniões e questões de interesse geral estão em interação com as peças literárias, pois deste modo a esfera pública ganhava interatividade popular e as tensões que envolve os mais diversos embates de opiniões divergentes.

Nesse sentido, o filósofo canadense sinaliza uma outra forma que adveio da teologia da Reforma que colaborou com a estipulação de ações metatópicas na vida secular. A movimentação reformatória trouxe uma nova estrutura para a realidade da vida religiosa ocidental que resultou na gestação de denominações cristãs. Estas passaram a ser associações que acolhiam pessoas que de forma voluntária e livre, independentemente de qualquer tipo de razão social ou familiar. A relevância que esta articulação ganha está em tensão com aquilo que diz respeito a vida em sua individualidade e a totalidade. O que vem à tona com isso é a construção de uma sociedade horizontalizada de acesso direito ao real, pois nestas não se admite mais nenhum tipo de mediação da parte de qualquer grupo superior no que tange a noção de pertença a estas sociedades. A gênese da esfera pública no continente europeu tem como pano de fundo a economia, sem descartar a vida eclesial e a vida íntima sentimental. Estas configurações podem ser identificadas como uma constelação de construções extrapolíticas e seculares que estão na base da estrutura social moderna.

Se por um ângulo a economia é considerada a esfera que mais se apartada do poder político, isto pelo fato de ser um domínio em que se não pressupõe qualquer espécie de publicidade deliberativa. De outro lado, esta esfera contribuiu com o fomento da de novas imagens referentes à soberania popular, pois estas deram origem por sua

JUNIOR, Joel Francisco Decothé; WESCHENFELDER, Kelvin Felipe. O pluralismo cultural dos imaginários sociais modernos segundo Charles Taylor. Griot : Revista de Filosofia, Amargosa - BA, v.19, n.2, p.250-264, junho, 2019. 
vez a algumas variações temerosas concernentes a ações políticas ao longo do século dezoito que forjaram a própria noção de aspiração por soberania popular. Taylor indica que um espaço extrapolítico, secular, metatópico reflete muito bem o que seja a esfera pública (TAYLOR, 2010). Assim, a relevância de se compreender tal fenômeno reside, em partes, no fato de que não este não se configurava como um único espaço livre de pressuposições em disputa de toda natureza na ordem moral vigente. Isso porque este estava inscrito numa evolução que gerou a mutação de toda a nossa compreensão do tempo e da sociedade, em relação ao que temos, inclusive aumentou a dificuldade de se ter uma memória nítida daquilo que esta era precedentemente ao movimento do devir filosófico da história na modernidade.

\section{Autogoverno como soberania democrática popular}

Ao adentrarmos na questão da soberania popular, podemos perceber que para Taylor a ênfase na legitimação da ordem social de um espaço pré-político, resulta no erguimento de múltiplas instâncias de debates e no reconhecimento do que foi se forjando coma a esfera pública. Neste sentido, a articulação de uma atitude ativa em termos de coletividade resultou naquilo que veio ser entendido como soberania popular. Na concepção de Taylor o filósofo que a expoente máxima desta nova concepção de soberania popular se chama Jean Jacques Rousseau. Com o filósofo genebrino as teorias da benevolência universal acabam por expressar certa ambiguidade de motivações que deveriam ser suplantadas ao ponto de poder assim conseguir determinada harmonia de motivos na convivência entre os seres humanos que compunham as malhas sociais modernas. A crítica de Rousseau as novas teorias da benevolência, se centraram na questão de que estas se apartavam da experiência genuinamente original da vida dos humanos, quando estas propunham uma elevação até uma visão amplamente universal que teria a função de tornar estas pessoas em expectadores imparciais. A suposição era a de que tal estado de coisas estaria fazendo o papel de libertar os poderes de benevolência natural da humanidade, pois a meta era fazer a espécie humana poder comtemplar de uma forma mais ilustrada uma forma de se conseguir atingir as metas que envolvessem os seus interesses pessoais.

Para Taylor, a partir da filosofia de Rousseau foi instaurada uma prática racional fomentada por uma espécie de pensamento que quis ser estratégico, pois ao se voltar para a vida da natureza humana em suas formas mais dependentes dos demais, desvela o sentido mais funcional de controlá-la e manipulá-la com interesses diversos. Simultaneamente a isto não acontecia a satisfação das necessidades de produção de estima que avaliava como algo imanente a vida de todas as pessoas. Assim, Taylor expõe o que Rousseau articula sobre este pensamento estratégico "o si mesmo estratégico, que está, ao mesmo tempo, isolado e ansioso pela aprovação alheia, reprime ainda mais o verdadeiro si mesmo" (TAYLOR, 2010, p. 119). Diante desta perspectiva o pensamento rousseniano, proporia não uma atitude de desinteresse por parte de um expectador de tipo imparcial, porém a proposta é a do retorno ao mais íntimo e substancial nos seres humanos. O que Rousseau indica é a realidade dos instintos primitivos do amor a si mesmos e da compaixão que se jungia no ser humano racional e virtuoso que lhe conferiria as condições de amar ao bem comum, algo que seria denominado pelo filosofo genebrês de vontade geral.

JUNIOR, Joel Francisco Decothé; WESCHENFELDER, Kelvin Felipe. O pluralismo cultural dos imaginários sociais modernos segundo Charles Taylor. Griot : Revista de Filosofia, Amargosa - BA, v.19, n.2, p.250-264, junho, 2019. 
Em confrontação com uma perspectiva mais geral de amor o que se tem é um contraponto que é o resultado de uma visão fraturada deste sentimento mais universal. $O$ resultado anômalo desta posição afetiva de amor universalista, se dó com o sentimento de amor próprio que tem os seus limites circunscritos no campo de busca por uma espécie de bem-estar individual. Vejamos que a partir da leitura de Rousseau, temos o diagnóstico desta anomalia liberal que é precisamente posto pelo fato de a desigualdade social não poder gerar efetivamente o estado de bem-estar em termos coletivos (COUTINHO, 2011). Como consta a meta da posição filosófica de Rousseau seria a de tentar conciliar as vontades individuais, para tanto ela aplicará a noção de construção de uma nova identidade comum, saber, a vontade geral. Senda assim, apenas por meio desta, é que se constituirá o esforço de todos os agentes livres em se afirmarem e por isso garantirem desta forma as forças de suas liberdades individuais buscam receber em bloco as benesses como parte indivisível do todo (ROUSSEAU, 2017). A partir da análise tayloriana, tanto este conceito, como a noção de insurgência popular são categorias ativas derivadas de uma extensa gama de acontecimentos e práticas históricas que contribuíram para a construção da própria concepção de vontade popular.

Ademais, conforme esta perspectiva os sujeitos foram deixando de lado aquela espontaneidade de grupos civis, pois passam a ostentar a própria volição de uma forma avaliativa forte. Esta atitude não está atrelada a nenhum tipo de dependência última no que concerna aos governantes, sendo o giro político realizado no sentido de que a partir destas circunstâncias, estes governantes é que serão supervisionados e avaliados pelas pessoas cidadãs. Com a afirmação desta modalidade de vontade própria sendo exercida em sua inteireza, o que se percebe é que o usufruto da capacidade de construção de uma nova ordem moral nas sociedades modernas cada vez mais se distancia do paradigma pré-moderno da fundamentação política de cunho transcendente. Taylor esboça a noção de que no curso da história moderna, "as condições sociais de liberdade se desenvolveram com a exigência de auto compreensão do agente humano por si mesmo, sendo pautado pelo imperativo de constituição de sua autonomia na condução de sua própria vida" (TAYLOR, 2005, p. 254). Portanto, quando se aborda esta faceta do imaginário moderno o que se deseja para Taylor, é o destaque que se faz para dentro do escopo da filosofia rousseauniana que coloca em voga uma concepção inovadora sobre a vida do agente moral que ficou marcada na vida cultural da modernidade.

Nesta interseção com a filosofia de Rousseau, Taylor apontará que dois tópicos são importantes no quadro teórico geral do pensamento do pensador genebrês: (i) o fato de se sustentar que a afirmação da dependência de todos os agentes em relação a vontade geral como condição de possibilidade da liberdade pessoal, com Rousseau o que se fomenta é a ruptura com a compreensão que tinha sido imperativamente vigente por muitos séculos, e que se centrava na condição hierarquizada de identidade. Nas sociedades em que afirmou a noção de vontade geral como condição de possibilidade do exercício da liberdade das pessoas, faz-se necessário que todos os agentes se tratem como iguais. Esta articulação causará os desdobramentos da gênese de determinada compreensão igualitarista da dignidade e da liberdade da vida humana que será uma aporia marcante da gramática moral da vida do agente humana no seio da ordem moral moderna. Num outro diapasão: (ii) a

JUNIOR, Joel Francisco Decothé; WESCHENFELDER, Kelvin Felipe. O pluralismo cultural dos imaginários sociais modernos segundo Charles Taylor. Griot : Revista de Filosofia, Amargosa - BA, v.19, n.2, p.250-264, junho, 2019. 
sustentação teórica se movimenta no sentido da proposição de um retorno fundamental as experiências mais íntimas dos seres humanos como condição de possibilidade de concretização do bem comum.

Esta postura fomentará outra visão sobre a compreensão da liberdade e da identidade pessoal que culminará na questão referente a uma perspectiva de ética da autenticidade. Com isso, sociedades democráticas, o imaginário popular em sua faceta de soberania popular, mostra a impessoalidade das leis, a igualdade diante das leis, a divisão dos poderes, a autonomia diante do Estado assim como série de direitos civis, políticos e de expressão na esfera pública foram se impondo. Nesta ordem moral moderna, a suposição de que o povo soberano seja a fonte moral para toda a legalidade das leis. Com efeito, existem diferenças notáveis entre os imaginários presentes nos mais diversos países quando se fala da construção da soberania popular. O relevante neste quadro é o dado de que os imaginários sociais modernos alimentam uma gama de práticas dos agentes sociais que lhes confere sentido em seus agir. No pano de fundo moral moderno faz-se muito importante ter a real noção do que se está fazendo, pois o que tem como objetivo maior é o de se levar me frente algumas condutas que ponham em prática os axiomas concernentes a estes imaginários em suas prescrições normativas (GIROLA, 2007, p. 55). Os agentes têm o desafio de estarem de acordo com aquilo que elas realmente são em tensão com as proposições deste pluralismo de imaginários sociais modernos.

O destaque para as grandes diferenças entre a sociedade pré-moderna e a moderna propriamente dita, foi produzida na vertente da diferença das ideias se tem acerca do peso das instituições, das mobilizações populares, do valor que o sufrágio foi ganhando e a aporia da noção de representatividade democrática que implica questões referentes a transparência e deliberação nos regimes democráticos. Logo, com o desenvolvimento da democracia as oposições não ficaram fora do jogo democrático, pois as rivalidades entre os governos nascentes como Estado-nação em processo de democratização e os seus oponentes. O pressuposto de que a democracia seja continuamente uma possibilidade de responsividade do governo às preferências de seus cidadãos, considerados como politicamente iguais e avo das ações afirmativas populares do sistema democrático tendo vista o bem-estar de seus cidadãos soberanos (DAHL, 2015, p. 25-26). Somos levados a pensar que o ponto de distinção nesta discussão sobre o imaginário social moderno, desvela que o pano de fundo dos indivíduos implica numa novidade de concepção estrutural mental de temporalidade, nesta estrutura mental, as sociedades de acesso direto mostram que a constituição do Estado-nação não necessita mais o que qualquer tipo de instancia fundante de caráter transcendente (TAYLOR, 2011, p. 86-88). O que resta apenas é a articulação da problemática sobre a via de uma ação comunitária que envolve os indivíduos que se entendem como livres e iguais numa era secular

\section{Considerações finais}

À medida que acompanhamos os argumentos de Taylor sobre o problema dos imaginários sociais, podemos perceber que estes são constitutivos da ordem moral moderna. Logo, para o filósofo canadense, aconteceu uma transição das consagradas teorias jusnaturalistas, que de um modo geral sempre esteve sob a égide do poder das

JUNIOR, Joel Francisco Decothé; WESCHENFELDER, Kelvin Felipe. O pluralismo cultural dos imaginários sociais modernos segundo Charles Taylor. Griot : Revista de Filosofia, Amargosa - BA, v.19, n.2, p.250-264, junho, 2019. 
elites, para o contexto de nivelamento do imaginário social numa complexa ressignificação de imbricação dialética entre teoria e práxis. Senso assim, Taylor pontua que as três formas de aprofundamento do conhecimento social listados acima, foram centrais para a constituição da ordem moral moderna enquanto imaginários sociais. Tanto a economia, como a esfera pública e ainda o autogoverno popular e democrático. A pertinência da argumentação tayloriana encontra-se justamente calcada no fato de que a modernidade modificou significativamente o imaginário social, isso com as novas formas de práticas econômicas, ações na esfera pública e as reinvindicações cidadãs referente a questão da força que se impõe com a democracia. Ademais, esta realidade triádica impulsiona a segunda metade do século XVIII, com a concepção de uma ordem política que se estruturou deliberativamente com a articulação da própria noção de sociedade civil.

Segundo Taylor, o procedimento de acesso imediato aos imaginários está atrelado a noção de igualdade, mas sem deixar de lado a robusta afirmação do individualismo. Isso porque a pertença a comunidade se afirmar também desta forma, sendo aqui evidenciado o individualismo anônimo que reforça o imaginário da participação as entidades de uma forma cada vez mais impessoais, quer seja no fluxo do poder estatal ou na comunidade da humanidade em sua universalidade. Esta tríade que passa a compor os imaginários sociais modernos, confere o estofo necessário para a nova concepção de ordem moral nascente. Desta forma, as práticas normativas subjacentes a estas sociedades visam o estabelecimento das condições reais para que as mesmas sejam realizáveis. Todavia, o que se nota na reflexão do filósofo canadense é o dado de que as configurações do pano de fundo da ordem moral moderna, não mais estão presas a linguagem do direito natural exclusivamente, mas passa vigora a busca por benefícios mútuos e a luta pelos direitos individuais. Com o avanço da força da soberania popular, o consentimento em relação a estrutura da igualdade tem sido aplicada em múltiplos contexto sociais, isso representa que o nivelamento social na ordem moral ganha intensidade e densidade em relação as exigências da política que vai sendo forjada na modernidade.

A abordagem de Taylor se movimenta de uma forma tríplice, pois a ordem moral moderna reformula as descrições daquilo que venha a ser a noção de providência. Contudo, a importância desta categoria se tornou central para os arranjos políticos que atingem até os diais atuais as forças que governam a vidas dos indivíduos com as exigências de certos imperativos que configurarão os imaginários sociais modernos por meio de concepções éticas que visam estabelecer uma compreensão do mundo de forma abrangente. A partir disto, algumas implicações irão surgir tais como a luta por realização daquilo que seja pautado pelo que é correto, mesmo que isto venha se dar em partes. Isso porque nesta fase da ordem moral moderna, requer-se a justificação instrumental de toda e qualquer distribuição das funções que devem ser realizadas na sociedade por indivíduos livres, iguais e cooperativos. Então, o que marca esta transição é a concepção de igualdade como imperativo moral, portanto esta desconstrói a prática da hierarquia, pois acaba ficando em descrédito no fluxo constitutivo dos imaginários sociais, que vão contribuir para a construção da liberdade dos modernos.

JUNIOR, Joel Francisco Decothé; WESCHENFELDER, Kelvin Felipe. O pluralismo cultural dos imaginários sociais modernos segundo Charles Taylor. Griot : Revista de Filosofia, Amargosa - BA, v.19, n.2, p.250-264, junho, 2019. 


\section{Referências:}

ARAUJO, P. R. M de. Charles Taylor: para uma ética do reconhecimento. São Paulo: Edições Loyola, 2004.

BERGER, Peter L. Os múltiplos altares da modernidade rumo a um paradigma da religião numa época pluralista. Tradução de Noéli Correa de Melo Sobrinho; revisão da tradução de Gentil Avelino Titton. Petrópolis, RJ: Vozes, 2017.

COUTINHO, Carlos Nelson. De Rousseau a Gramsci: ensaios de teoria política. São Paulo: Boitempo, 2011.

DAHL, Robert A. Poliarquia: Participação e Oposição. Prefacio Fernando Limongi; tradução Celso Mauro Paciornik. - 1. Ed. 3 reimpr. - São Paulo: Editora Universidade de São Paulo, 2015.

FORERO REYES, Yelitsa. Marcela. Epifanías de la identidad: la comprensión multiculturalista de Charles Taylor. la ed. - Bogotá: Editorial Pontificia Universidad Javeriana, 2008.

OLIVEIRA, J. C. C da. Religião e secularismo em Charles Taylor: por uma modernidade múltipla. In: Filosofia e religião: fenômeno religioso no mundo (pós) secular [recurso eletrônico] / Antônio Glaudenir Brasil Maia (Org.) - Porto Alegre, RS: Editora Fi, 2018.

OLIVEIRA, Manfredo Araújo de. Ética e racionalidade moderna. São Paulo: Loyola, 1993.

GASDA, Élio Estanislau. Economia e bem comum: o cristianismo e uma ética da empresa no capitalismo. São Paulo: Paulus, 2016. - Coleção Ethos.

GIROLA, Lidia. Imaginarios socioculturales de la modernidad. Aportaciones recientes y dimensiones del análisis para la construcción de una agenda de investigación. Sociológica, vol. 22, núm. 64, mayo-agosto, 2007, pp. 45-76. Universidad Autónoma Metropolitana Distrito Federal, México. Disponível em: http://www.redalyc.org/articulo.oa?id=305024715003. Acesso em: 03 maio. 2018. HONNETH, Axel. O direito da liberdade. Tradução Saulo Krieger. São Paulo: Martins Fontes, 2015.

ROUSSEAU, Jean-Jacques. Emilio ou da educação. Tradução Laurent de Saes. São Paulo: Edipro, 2017.

TAYLOR, Charles. Encanto y desencantamiento: secularidad y laicidad en Occidente. Tradução de José Pérez Escobar. Maliaño (Cantabria): Editorial Sal Terrae, 2015.

TAYLOR, Charles. Argumentos filosóficos. Tradução Adail Ubirajara Sobral. 2. ed. São Paulo: Edições Loyola, 2014.

TAYLOR, Charles. As fontes do self: a construção da identidade moderna. Tradução de Adail Ubirajara Sobral e Dinah de Abreu Azevedo. 4. ed. São Paulo: Edições Loyola, 2013.

TAYLOR, Charles. Dilemmas and Connections: selected essays. Cambridge, Massachusetts, and London: The Belknap Press of Harvard University Press, 2011a. TAYLOR, Charles. Imaginários Sociais Modernos. Tradução: Artur Morão. $1^{\text {a }}$ edição, fevereiro de 2010. Lisboa: Edições Texto \& Grafia, 2010.

TAYLOR, Charles. Uma era secular. Tradução de Nélio Schneider e Luiza Araújo. São Leopoldo: Ed. UNISINOS, 2010 b.

JUNIOR, Joel Francisco Decothé; WESCHENFELDER, Kelvin Felipe. O pluralismo cultural dos imaginários sociais modernos segundo Charles Taylor. Griot : Revista de Filosofia, Amargosa - BA, v.19, n.2, p.250-264, junho, 2019. 
TAYLOR, Charles. La libertad de los modernos. Traducción de: Horacio Pons. $-1^{\mathrm{a}}$ ed. - Buenos Aires: Amorrortu, 2005.

VATTIMO, Gianni. Crer que se crê: é possível ser cristão apesar da Igreja? Tradução Klaus Brüschke. Petrópolis, RJ: Vozes, 2018.

Contribuição dos autores: Joel Francisco Decothé Junior, redigiu os tópicos do texto, o resumo em português, as considerações finais e fez a revisão do artigo. Kelvin Felipe Weschenfelder realizou a tradução do resumo do português para o inglês, escreveu a introdução e fez a revisão do texto. Ambos os autores aprovaram a versão final do texto.

Autor(a) para correspondência: Joel Francisco Decothé Junior, Universidade do Vale do Rio dos Sinos Av. Unisinos, 950, Cristo Rei, 93022-750, São Leopoldo - RS, Brasil. joeldecothe@yahoo.com.br 